\title{
Corrigendum: Social Daydreaming and Adjustment: An Experience-Sampling Study of Socio-Emotional Adaptation During a Life Transition
}

\author{
Giulia L. Poerio ${ }^{1 *}$, Peter Totterdell ${ }^{2}$, Lisa-Marie Emerson ${ }^{2}$ and Eleanor Miles ${ }^{3}$ \\ ${ }^{1}$ Department of Psychology, University of York, York, UK, ${ }^{2}$ Department of Psychology, University of Sheffield, Sheffield, UK, \\ ${ }^{3}$ School of Psychology, University of Sussex, Brighton, UK
}

Keywords: daydreaming, mind wandering, socio-emotional adaptation, social cognition, social emotion, emotional inertia, loneliness, experience-sampling

\section{A corrigendum on}

Social Daydreaming and Adjustment: An Experience-Sampling Study of Socio-Emotional Adaptation During a Life Transition

by Poerio, G. L., Totterdell, P., Emerson, L.-M., and Miles, E. (2016). Front. Psychol. 7:13. doi: $10.3389 /$ fpsyg.2016.00013

\section{OPEN ACCESS}

Edited and reviewed by: John M. Zelenski,

Carleton University, Canada

*Correspondence: Giulia L. Poerio

giulia.poerio@york.ac.uk

Specialty section:

This article was submitted to Personality and Social Psychology, a section of the journal

Frontiers in Psychology

Received: 27 January 2016 Accepted: 29 January 2016

Published: 12 February 2016

Citation:

Poerio GL, Totterdell P, Emerson L-M and Miles E (2016) Corrigendum: Social Daydreaming and Adjustment:

An Experience-Sampling Study of Socio-Emotional Adaptation During a Life Transition. Front. Psychol. 7:174. doi: 10.3389/fpsyg.2016.00174
The second and third authors affiliation was incorrectly stated as both the University of York and the University of Sheffield, which requires amendment (i.e., these authors are affiliated to the University of Sheffield only and not the University of York). This correction does not in any way affect the scientific validity of the results.

\section{AUTHOR CONTRIBUTIONS}

GP conceived of, and designed, the study in consultation with PT, LE, and EM. GP conducted the study and analyzed the data with assistance and contributions from PT. GP drafted the manuscript with contributions from PT, LE, and EM. All authors read and approved the final manuscript.

\section{FUNDING}

This research was supported by the Economic and Social Research Council [grant number ES-J500215-1] awarded to GP whilst at the University of Sheffield.

Conflict of Interest Statement: The authors declare that the research was conducted in the absence of any commercial or financial relationships that could be construed as a potential conflict of interest.

Copyright $\odot 2016$ Poerio, Totterdell, Emerson and Miles. This is an open-access article distributed under the terms of the Creative Commons Attribution License (CC BY). The use, distribution or reproduction in other forums is permitted, provided the original author(s) or licensor are credited and that the original publication in this journal is cited, in accordance with accepted academic practice. No use, distribution or reproduction is permitted which does not comply with these terms. 